\title{
MIR30A Pre-miRNA
}

National Cancer Institute

\section{Source}

National Cancer Institute. MIR30A Pre-miRNA. NCI Thesaurus. Code C82728.

MIR30A pre-miRNA is an oligoribonucleotide that is encoded by the human MIR30A gene and is involved in the regulation of gene expression. 